\title{
Bacterial pigment for Nile tilapia feeding
}

\author{
Thiago Luís Magnani Grassi ${ }^{1} \cdot$ Edson Francisco do Espírito Santo ${ }^{1}$ • \\ Marcelo Tacconi de Siqueira $\operatorname{Marcos}^{1} \cdot J_{\text {Jefferson Felipe Cavazzana }}{ }^{1}$. \\ Dayse Lícia Oliveira $^{1}$ - Iderlipes Luiz Carvalho Bossolani ${ }^{1}$ • \\ Elisa Helena Giglio Ponsano ${ }^{1}$
}

Received: 10 March 2015/Accepted: 19 October 2015/Published online: 23 October 2015

(C) Springer International Publishing Switzerland 2015

\begin{abstract}
The aim of this study was to evaluate the effects of different carotenoids sources in tilapia fish diets on the animals' performance and fillets characteristics. Nine hundred and sixty tilapias, Oreochromis niloticus, averaging $15 \mathrm{~g}$ were distributed into 24 tanks to receive one of the six treatments (four repetitions) for 80 days: basal diet with no pigment (control group), basal diet with $350 \mathrm{mg} / \mathrm{kg}$ astaxanthin $10 \%$ and basal diets added of four different concentrations of Rubrivivax gelatinosus biomass (175, 350, 700 and $1400 \mathrm{mg} / \mathrm{kg}$ ). Variables analyzed included feed consumption, weight gain, feed conversion and specific growth rate for the animals and $\mathrm{pH}$, proximate composition, carotenoids, polyunsaturated fatty acids and color for the fillets. Productive parameters did not differ statistically. Moisture content was lower on the fillets of treatments with pigments. The protein contents on the fillets of diets supplemented with the bacterial biomass were higher than in control group, while $\mathrm{pH}$, minerals and lipids did not vary among treatments. Lightness and yellowness did not differ among the treatments, but redness and carotenoids contents were higher for all the groups that received the pigments than for the control group. The ratio of polyunsaturated fatty acids n-6/n-3 was improved with the dietary biomass. So, it was concluded that the use of the pigmenting ingredients did not alter productive parameters but increased redness and carotenoids contents in the fillets. Moreover, the use of $R$. gelatinosus biomass also increased the protein contents and improved the fatty acids profile in the fillets.
\end{abstract}

Keywords Antioxidants - Aquaculture - Carotenoids · Color · Growth performance · Oreochromis niloticus $\cdot$ Polyunsaturated fatty acids · Proximate composition

Thiago Luís Magnani Grassi

thiagograssi@hotmail.com; thiagograssi@fmva.unesp.br

1 Departamento de Apoio, Produção e Saúde Animal, Faculdade de Medicina Veterinária, Unesp Univ. Estadual Paulista - Campus Araçatuba, Araçatuba, São Paulo 16050-680, Brazil 


\section{Introduction}

The dissemination of information about fish meat nutritional value and its benefits to health is the responsible for the growing interest for fish products (Burger 2008). In order to reach this increasing demand, the traditional extensive raising systems are gradually being replaced for the intensive and semi-intensive fish farming (Watanabe et al. 2002). All over the world, Nile tilapia (Oreochromis niloticus) is the main cultivated species in aquaculture due to the high growth rate and adaptability to different raising systems, besides the good acceptance of the consumer market (Kubitza 2000; FAO 2014).

Color, nutritional value and appearance are subconscious elements involved in the choice for a food item among the available options (Diler and Dilek 2002). The reddish hue of some fish is a distinctive attribute that adds value to the derived products rendering them a higher status in the market (Takahashi et al. 2008). Thus, the use of carotenoids in the diets of fish with economic importance like cichlids and ornamentals is a matter of interest in aquaculture (Sefc et al. 2014).

Carotenoids are lipophilic substances widely used in food industry due to its pigmenting and antioxidant properties (Stahl and Sies 2003). For humans, some of them may act as pro-vitamin A source, increase the immune response and prevent cancer and coronary diseases (Britton et al. 2009; Park et al. 2009). In aquaculture, carotenoids may be used in fish diets as a way of bringing color to flesh, making it similar to what happens in nature (Baker et al. 2002).

Carotenoids may be synthesized by plants, yeasts, molds, algae and bacteria while animals must get them from diets (Chociai et al. 2002; Bhosale and Bernstein 2005). According to Oliveira et al. (2009), the world production of natural carotenoids is estimated in 100 millions ton per year, which represents an income of more than one billion dollars. Synthetic astaxanthin is widely used in aquaculture to provide color due to its ability to build up in the skin, muscles, gonads and eggs of fish (Meyers and Chen 1982). More than providing bright color to fish muscles, the dietary astaxanthin reduces lipid peroxidation and so improves fish fillets quality (Brambilla et al. 2009).

Nevertheless, the consumers' worries on synthetic additives in food, the legal restrictions to this pigment applied in some countries and the instability on the carotenoids composition in plants due to cultivation and harvesting conditions have directed the interest of food industries on carotenoids produced by biotechnology (Silva 2004; Bhosale and Bernstein 2005; Breithaupt 2007; Oliveira et al. 2009).

Rubrivivax gelatinosus is a phototrophic bacterium with the ability to grow in industry wastewaters consuming organic compounds and producing a biomass containing carotenoids that may find use as a pigment in animal diets to provide color to edible products (Ponsano et al. 2003, 2011). Recent researches using the bacterial biomass for tilapia feeding also indicated the ability of the carotenoids in decreasing the lipid oxidation in meat (Santo 2014). Nevertheless, the influence of the biomass on the fatty acids profile of the meat was not elucidated to date.

The aim of this work was to evaluate the effects of different sources and concentrations of dietary carotenoids on tilapias' performance and on the quality attributes of their fillets. 


\section{Materials and methods}

\section{Ethical approval, experimental design and treatments}

The experimental procedures were approved by the local Ethics Committee on the Use of Animals (CEUA/FOA 2013/01329). A completely randomized design with six treatments and four repetitions was adopted. Nine hundred and sixty fish averaging $15 \mathrm{~g}$ were distributed into 24 tanks (1000 L) (40 fish/tank) to receive the experimental diets: T1 - basal diet with no added pigments (control group); T2-basal diet plus Carophyll Pink (astaxanthin $10 \%$, DSM); T3, T4, T5 and T6-basal diets plus Rubrivivax gelatinosus biomass at different concentrations (Table 1). The basal diet was especially formulated for fish, according to Furuya et al. (2010) and contained (dry basis) crude protein $30.52 \%$, crude lipid $6.41 \%$ and ash $7.99 \%$ (Table 1). The lyophilized bacterial biomass contained approximately $3 \%$ moisture, $60 \%$ protein and $3 \mathrm{mg} / \mathrm{g}$ carotenoids. Animals were fed the experimental diets thrice a day, ad libitum, during 80 days. The sediments deposited on the bottom of the tanks were removed by siphoning once a week, and the water quality was monitored twice a week. All the water parameters were kept in optimum range (temperature $27^{\circ} \mathrm{C}, \mathrm{pH} 7, \quad \mathrm{DO}>5.5 \mathrm{mg} / \mathrm{L}$, nitrate $<0.8 \mathrm{ppm}, \mathrm{NH}_{3}<0.004 \mathrm{ppm}$, chloride $<0.001 \mathrm{ppm})$. At the end of the experiment, fish were anesthetized with benzocaine at $0.1 \mathrm{~g} / \mathrm{L}$ and slaughtered by sectioning the gills, and the fillets were removed for the laboratory analyses.

\section{Growth performance}

Fish were weighed at the beginning and at the end of the experiment, and the growth performance was assessed on final weight (FW), weight gain (WG), feed consumption (FC), feed conversion ratio (FCR) and specific growth rate (SGR).

\section{Determination of the $\mathrm{pH}$}

For the determination of the $\mathrm{pH}, 10 \mathrm{~g}$ of the fish muscle samples was homogenized with $100 \mathrm{~mL}$ deionized water, and the measurement was taken using a pHmeter (Digimed DM22) at $25^{\circ} \mathrm{C}$.

\section{Proximate composition}

Proximate chemical composition analyses of the fish fillets included moisture (oven at $105{ }^{\circ} \mathrm{C}$ ), crude proteins (micro Kjeldahl) and total minerals (oven at $550{ }^{\circ} \mathrm{C}$ ) and were performed according to Horwitz and Latimer Jr. (2006). Total lipids were determined according to Folch et al. (1957).

\section{Color attributes}

The CIEL $a b$ colors of fish fillets ( $L=$ lightness; $a=$ redness; $b=$ yellowness) were obtained in triplicate by using portable MiniScan XE Plus equipment (Hunterlab) previously calibrated with white and black standards and using $10^{\circ}$ observer angle and illuminant D65. Measurements were taken above the lateral line of the muscles at three points (head, middle and tail), and the mean values were considered (Choubert et al. 1997). 
Table 1 Experimental diets for tilapias

\begin{tabular}{|c|c|c|c|c|c|c|}
\hline & \multicolumn{6}{|c|}{ Treatments } \\
\hline & $\mathrm{T} 1$ & $\mathrm{~T} 2$ & $\mathrm{~T} 3$ & $\mathrm{~T} 4$ & T5 & T6 \\
\hline \multicolumn{7}{|l|}{ Ingredients } \\
\hline Ground corn $(\%)$ & 6.42 & 6.42 & 6.42 & 6.42 & 6.42 & 6.42 \\
\hline Poultry meal by-products (\%) & 8 & 8 & 8 & 8 & 8 & 8 \\
\hline Soybean meal (\%) & 45 & 45 & 45 & 45 & 45 & 45 \\
\hline Wheat meal $(\%)$ & 17 & 17 & 17 & 17 & 17 & 17 \\
\hline Broken rice $(\%)$ & 7.6 & 7.6 & 7.6 & 7.6 & 7.6 & 7.6 \\
\hline Whole rice meal $(\%)$ & 5 & 5 & 5 & 5 & 5 & 5 \\
\hline Meat meal $(\%)$ & 6 & 6 & 6 & 6 & 6 & 6 \\
\hline Binder $(\%)$ & 0.1 & 0.1 & 0.1 & 0.1 & 0.1 & 0.1 \\
\hline Salt $(\%)$ & 0.3 & 0.3 & 0.3 & 0.3 & 0.3 & 0.3 \\
\hline Dicalcium phosphate (\%) & 1.32 & 1.32 & 1.32 & 1.32 & 1.32 & 1.32 \\
\hline Soybean oil $(\%)$ & 2.13 & 2.13 & 2.13 & 2.13 & 2.13 & 2.13 \\
\hline Choline chloride $70(\%)$ & 0.2 & 0.2 & 0.2 & 0.2 & 0.2 & 0.2 \\
\hline DL-methionine (\%) & 0.22 & 0.22 & 0.22 & 0.22 & 0.22 & 0.22 \\
\hline Antifungal (Fylax) (\%) & 0.2 & 0.2 & 0.2 & 0.2 & 0.2 & 0.2 \\
\hline Mineral and vitamin $\operatorname{mix}^{\mathrm{a}}(\%)$ & 0.5 & 0.5 & 0.5 & 0.5 & 0.5 & 0.5 \\
\hline Carophyll Pink (astaxanthin $10 \%)(\mathrm{mg} / \mathrm{kg})$ & 0 & 350 & 0 & 0 & 0 & 0 \\
\hline R. gelatinosus biomass (mg/kg) & 0 & 0 & 175 & 350 & 700 & 1400 \\
\hline \multicolumn{7}{|l|}{ Nutrients/energy_calculated values } \\
\hline Digestible energy (kcal/kg) & 3000 & 3000 & 3000 & 3000 & 3000 & 3000 \\
\hline Digestible protein $(\%)$ & 27.2 & 27.2 & 27.2 & 27.2 & 27.2 & 27.2 \\
\hline Crude protein $(\%)$ & 32 & 32 & 32 & 32 & 32 & 32 \\
\hline Ether extract $(\%)$ & 6 & 6 & 6 & 6 & 6 & 6 \\
\hline Crude fiber $(\%)$ & 4.5 & 4.5 & 4.5 & 4.5 & 4.5 & 4.5 \\
\hline Mineral composition (\%) & 9 & 9 & 9 & 9 & 9 & 9 \\
\hline Total calcium (\%) & 1.63 & 1.63 & 1.63 & 1.63 & 1.63 & 1.63 \\
\hline Total phosphorus (\%) & 1.3 & 1.3 & 1.3 & 1.3 & 1.3 & 1.3 \\
\hline Starch $(\%)$ & 22 & 22 & 22 & 22 & 22 & 22 \\
\hline Available phosphorus (\%) & 0.7 & 0.7 & 0.7 & 0.7 & 0.7 & 0.7 \\
\hline Lysine (\%) & 2 & 2 & 2 & 2 & 2 & 2 \\
\hline Threonine (\%) & 1.2 & 1.2 & 1.2 & 1.2 & 1.2 & 1.2 \\
\hline Tryptophan (\%) & 0.35 & 0.35 & 0.35 & 0.35 & 0.35 & 0.35 \\
\hline Methionine (\%) & 0.65 & 0.65 & 0.65 & 0.65 & 0.65 & 0.65 \\
\hline Vitamin C (mg/kg) & 300 & 300 & 300 & 300 & 300 & 300 \\
\hline Calcium/total phosphorus & 1.5 & 1.5 & 1.5 & 1.5 & 1.5 & 1.5 \\
\hline
\end{tabular}

${ }^{a}$ Composition per $\mathrm{kg}$ of the product: vitamin A 2,400,000 UI; vitamin D3 600,000 UI; vitamin E 30,000 mg; vitamin K3 3000 mg; vitamin B1 4000 mg; vitamin B2 4000 mg; vitamin B6 3500 mg; vitamin B12 $8000 \mathrm{mg}$; vitamin C $60,000 \mathrm{mg}$; nicotinic acid 20,000 mg; pantothenic calcium 10,000 mg; biotin $200 \mathrm{mg}$; folic acid $1200 \mathrm{mg}$; Cu $3500 \mathrm{mg}$; Fe 20,000 mg; Mn 10,000 mg; Zn 24,000 mg; Ca $160 \mathrm{mg}$; Na $100 \mathrm{mg}$; Co $80 \mathrm{mg}$; inositol 25,000 mg; choline chloride 100,000 mg 


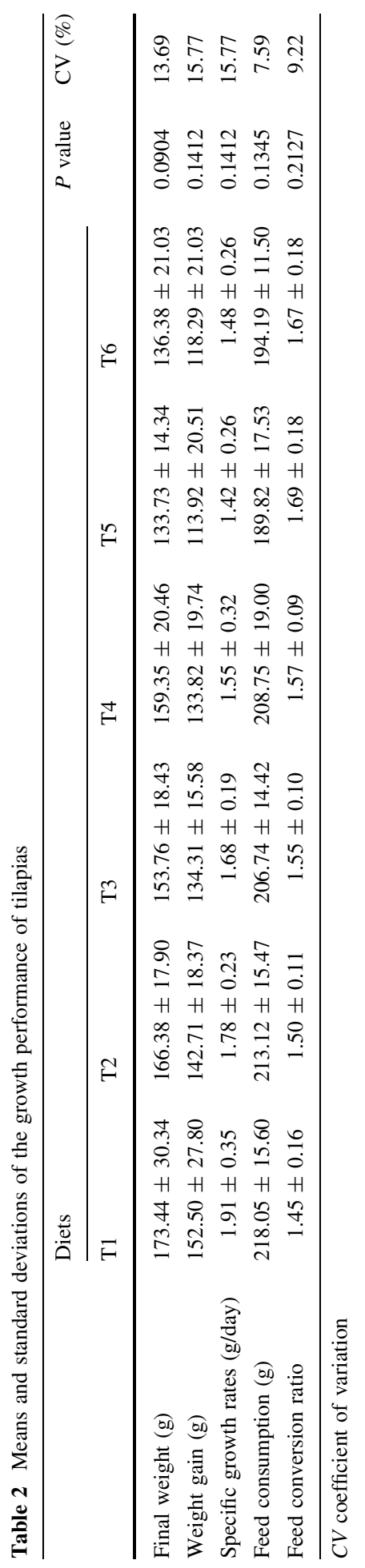




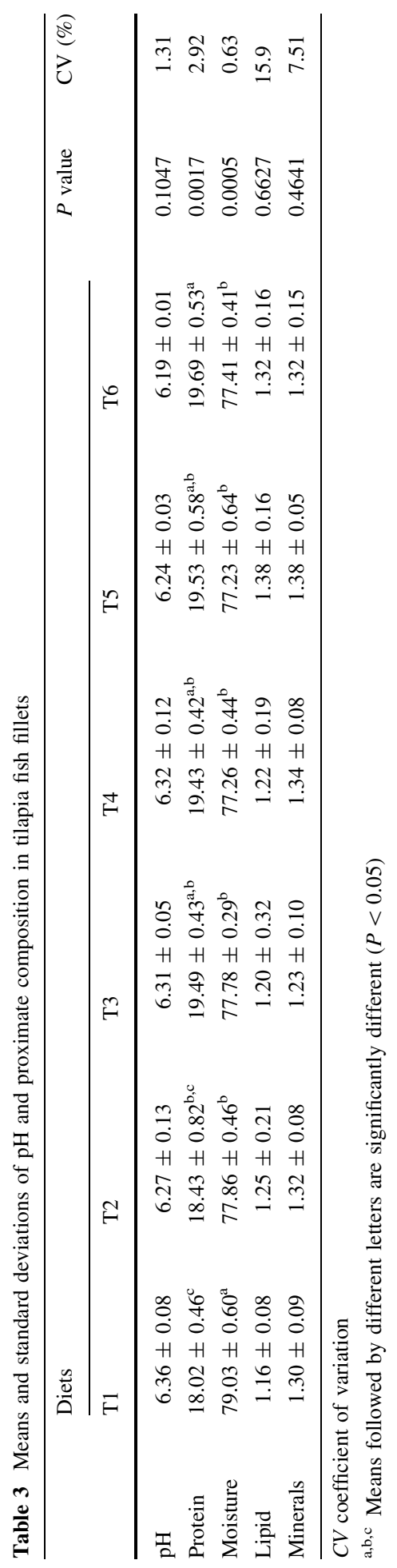




\section{Carotenoids content}

Prior to the carotenoids extraction, the fish fillets were freeze-dried at $-35{ }^{\circ} \mathrm{C}$ for $48 \mathrm{~h}$ and ground to powder. Then, samples of the lyophilized fillets were vortexed with dimethyl sulfoxide and sonicated for $15 \mathrm{~min}$ at $40{ }^{\circ} \mathrm{C}$. The extraction was performed repeatedly with acetone. The phase separation was attained with diethyl ether and distilled water, and the hyperphase was dried under $\mathrm{N}_{2}$ stream. The extract was suspended in ethanol, and total carotenoids were calculated from the absorbance at $475 \mathrm{~nm}$, using 2500 as the coefficient of extinction.

\section{Fatty acids (FA) analyses}

FA were extracted and methylated following Christie (1975) and Hara and Radin (1978) methodologies and then analyzed by HPLC (Focus CG-Finnigan, Saint Louis, MO, USA/ CP-Sil 88 column $0.25 \mu \mathrm{m}$ i.d.; $100 \mathrm{~m} ; 0.20 \mu \mathrm{m}$ film thickness; Varian, Sigma-Aldrich Inc., Saint Louis, MO, USA). Different mobile phases and flow rates were used to optimize the separation conditions. Peaks were identified by comparison of the retention times of pure FA standards (Supelco, Sigma-Aldrich Inc., Saint Louis, MO, USA), and their areas were expressed as percentages of each fatty acids.

\section{Statistical analysis}

All data collected were subjected to analysis of variance, and the significance of differences between means was tested by Tukey's test $(P<0.05)$ using Action ${ }^{\circledR}$ version 2.7 . Broken line regression was used to estimate the biomass requirements for the significant variables, and the polynomial regression was used to predict the relationship between redness and carotenoids content. The significance level was set at 0.05 .

\section{Results and discussion}

The growth indicators did no differ statistically $(P>0.05$, Table 2$)$, which means that the use of the pigmenting ingredients tested did not influence the animals' productive performance. Moreover, no mortality was observed during the experiment. These rates are very variable for tilapia, since factors such as rearing conditions, feed composition, fish age and time of feeding may influence them. Even so, they are in agreement with data found by $\mathrm{Hu}$ et al. (2006) after feeding tilapia hybrids with beta-carotene for 10 weeks.
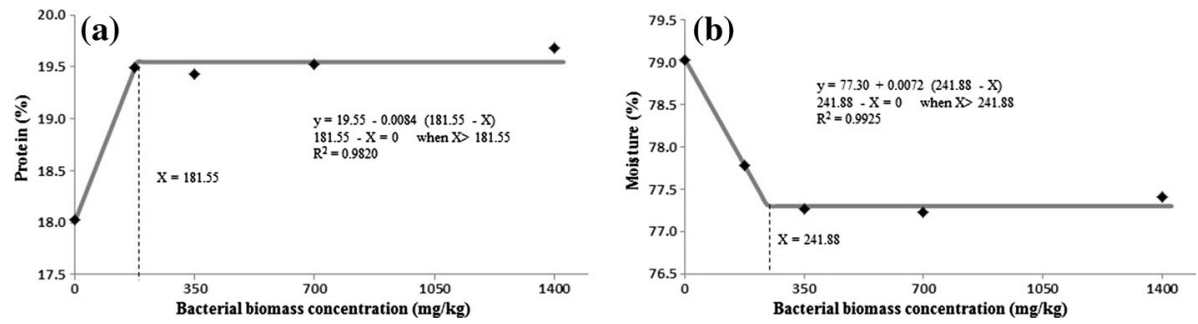

Fig. 1 Broken line plot of protein (a) and moisture (b) in tilapia fillets as a function of the bacterial biomass concentration in the diets 


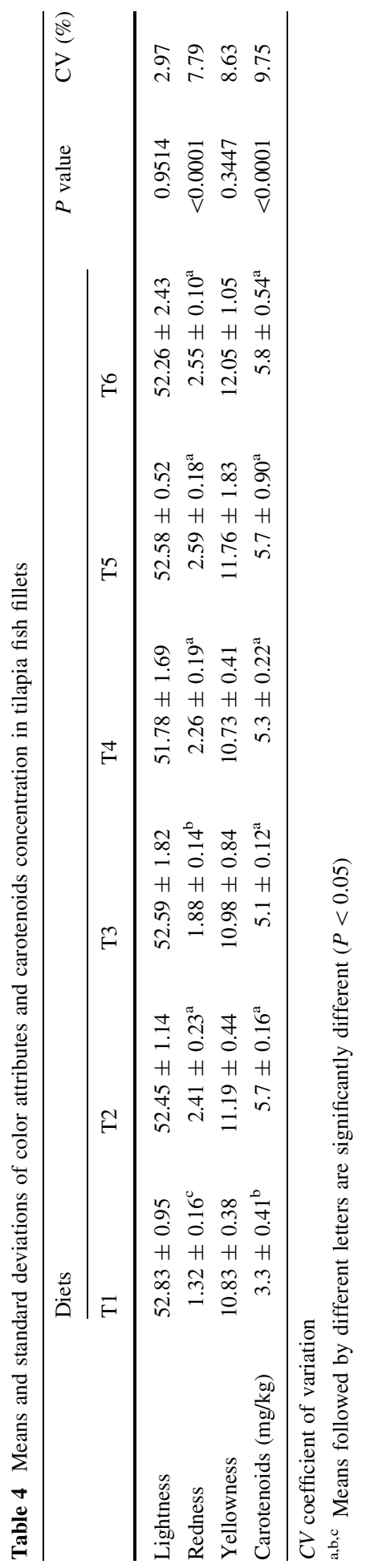


The fillets $\mathrm{pH}$ ranged from 6.19 to 6.36 and also did not differ significantly between treatments $(P>0.05$, Table 3$)$. According to Pacheco-Aguilar et al. (2000), the final flesh $\mathrm{pH}$ depends on many factors such as species, feeding and slaughtering, localization at the capture, temperature during storage and the meat buffering capacity. Among these factors, feeding was the only variable one, so it is possible to affirm that none of the pigmenting ingredients used in the study influenced the final $\mathrm{pH}$. Data found for $\mathrm{pH}$ in this experiment are similar to the ones reported by Albuquerque et al. (2004), Moura et al. (2009) and Chaijan (2011) for fish muscle.

For all treatments, the protein contents on the fillets were at the range of 15-20\% (Table 3), considered as normal for tilapia (Puwastien et al. 1999; Justi et al. 2003; Yanar et al. 2006; Emire and Gebremariam 2009). However, the use of the bacterial biomass in the diets increased the protein deposition in the muscles. According to the broken line shown in Fig. 1a, the use of $181.55 \mathrm{mg}$ biomass $/ \mathrm{kg}$ diet is enough to provide the higher protein content $(19.55 \%)$ on the fillets $\left(R^{2}=0.9820\right)$. It is reasonable to believe that the biomass exerted some probiotic effect on the utilization of the nutritional components of the diets inducing such a finding, although the elucidation for this mechanism was not the aim of this study. Takeuchi et al. (2002) also reported an increase in the protein content of the fillets of tilapia fed Spirulina, a natural antioxidant pigment synthesized by Spirulina platensis, although they have not assigned the reason for that finding.

On the other hand, the moisture content was lower on the fillets of the groups that received the carotenoids, with $241.88 \mathrm{mg}$ biomass $/ \mathrm{kg}$ diet being enough to provide the lower moisture content in the fillets $\left(77.3 \% ; R^{2}=0.9925\right)$ (Table 3; Fig. 1b). An explanation for this finding is that in a proximate analysis, one component decreases, while another increases, as it happened in this study for moisture and protein contents. This seems to be a positive feature for the fillets, regarding the microbiological stabilization of food products with lower moisture contents (Duan et al. 2004). These values are also in agreement with data on moisture contents of tilapia fillets found by other authors (Puwastien et al. 1999; Takeuchi et al. 2002; Justi et al. 2003; Yanar et al. 2006; Emire and Gebremariam 2009; Rocha et al. 2012).

It is known that the concentrations of lipids and minerals in fish flesh are related to the feeding, but, as the concentrations of these components were constant in the experimental diets and the feed consumption was the same among the groups, their contents also did not differ significantly in the tilapias fillets. Thus, the dietary pigments, which varied in the compositions of the rations, were not able to influence the lipids and the mineral contents in the muscles $(P>0.05$; Table 3$)$. These data are in agreement with the data reported by
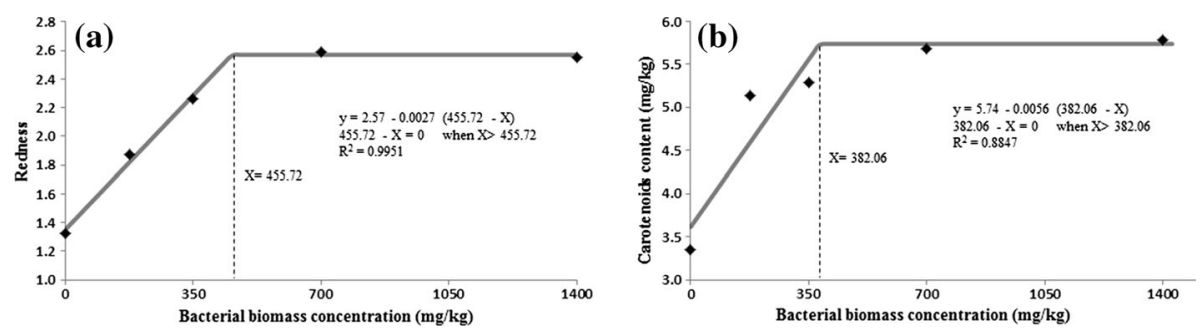

Fig. 2 Broken line plot of redness (a) and carotenoids (b) as a function of the bacterial biomass concentration in the diets 
other authors who fed pigments to fish (Puwastien et al. 1999; Justi et al. 2003; Yanar et al. 2006).

Lightness and yellowness were not significantly influenced by the dietary treatments, while redness was higher for all the groups that received carotenoids (Table 4). This was an expected result, since it is known that the carotenoids sources used in this experiment are able to increase this color attribute (De la Mora et al. 2006; Ponsano et al. 2011; Yesilayer and Erdem 2011). According to Diler and Dilek (2002), diets for farmed fish must be supplemented with pigments as a way to prevent consumers' rejection for the pale and greyish color of their flesh.

Results show that $R$. gelatinosus biomass at $175 \mathrm{mg} / \mathrm{kg}$ was already enough to provide redness increase, but concentrations above $350 \mathrm{mg} / \mathrm{kg}$ were necessary to reach the same redness provided by the synthetic astaxanthin (Table 4). The broken line analysis performed for the treatments containing the biomass (Fig. 2a) showed that $455.72 \mathrm{mg}$ of the product $/ \mathrm{kg}$ diet were enough to provide the highest redness $(a=2.57)$, with $99.51 \%$ of adjustment. $R$. gelatinosus biomass was previously used to improve broiler meat color (Ponsano et al. 2012); however, this was the first time the product was used as a pigment for fish feeding. So, the results presented herein corroborate the possibility of using this product for the pigmentation of cultivated tilapia.

According to Lovshin (2000), for the sale as a whole, red tilapias achieve a higher market value than Nile tilapia due to the attractive reddish hue of their skin, although both species show white fillets. The dietary administration of $R$. gelatinosus biomass to provide the fillets pigmentation may represent an option to diversify the offer to consumers and add value to the product.

The use of the pigments in the diets also caused significant increases in the carotenoids contents of the fillets (Table 4; Fig. 2b), with $382.06 \mathrm{mg}$ biomass $/ \mathrm{kg}$ diet being enough to provide the highest carotenoids content, $5.74 \mathrm{mg} / \mathrm{kg}\left(R^{2}=0.8847\right)$. Moreover, the quadratic equation presented in Fig. 3 shows that the increase of the carotenoids in the fillets explains $96.37 \%$ of the redness increase, which corroborates the red pigmenting ability of this product. Nevertheless, it was not found a significant effect of the kinds of the pigments tested on the carotenoids contents of the fillets. That means that both sources of carotenoids used have the same ability to deposit on the fish muscles. The deposition of carotenoids on fish fillets was also described by other authors who believe that the use of these biological active substances in fish diets may improve its quality properties due to the important role they play at humans' health (Yesilayer and Erdem 2011; Czeczuga et al. 2013).

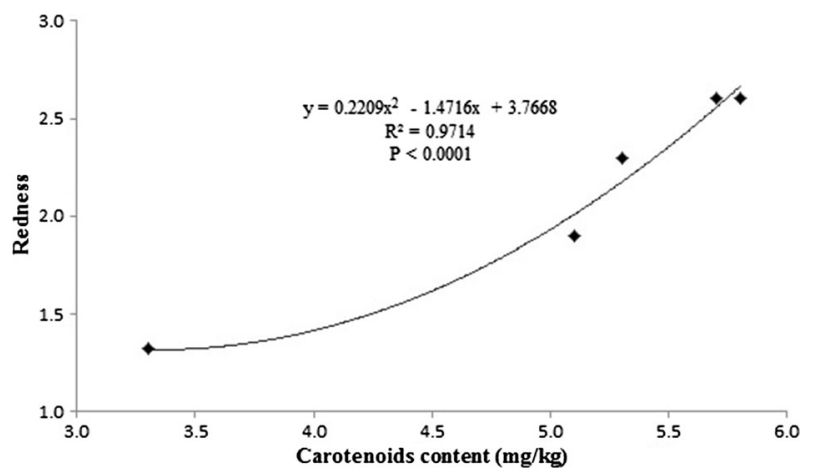

Fig. 3 Quadratic regression of redness as a function of the carotenoids concentration in the fillets 


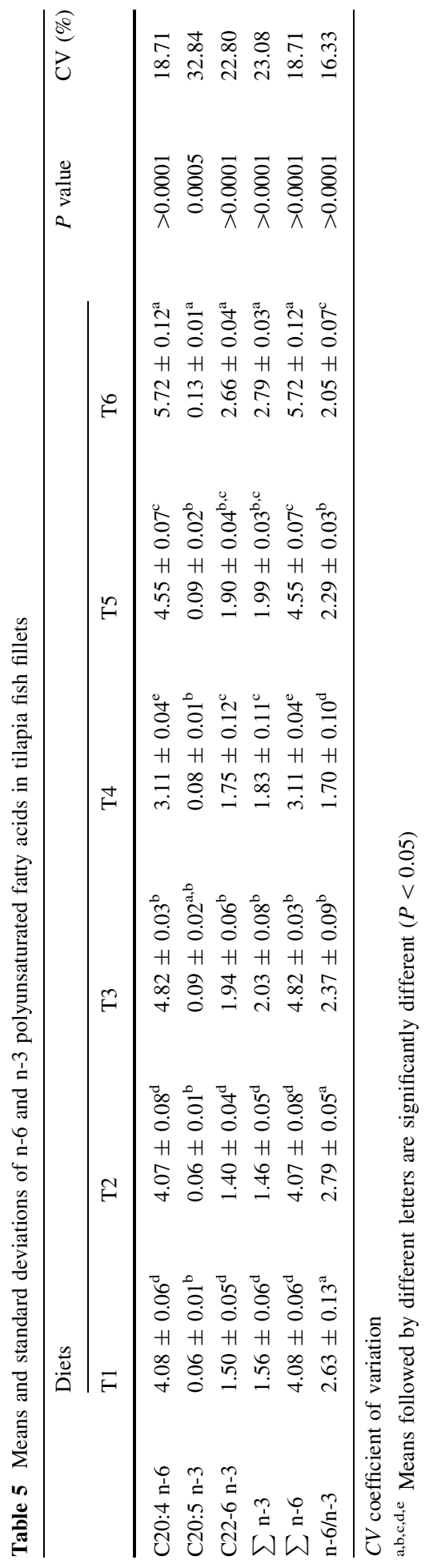


Yet in humans, the dietary n-3 polyunsaturated fatty acids (PUFA) such as eicosapentaenoic acid (C20:5 n-3) and docosahexaenoic acid (C22-6n-3) are engaged in various physiological processes and are essential for normal growth and development (Simopoulos 1999). They also play an important role in the prevention of cardiovascular and inflammatory diseases and, further, have promising antihypertensive, anticancer, antioxidant, antidepression, antiaging and antiarthritis function (Siriwardhana et al. 2012). On the other hand, the excessive dietary n-6 PUFA is associated with the prevalence of various chronic diseases (Simopoulos 2002).

Since n-3 and n-6 PUFA have different effects on human health, an appropriate ratio of both in the diet is crucial (Strobel et al. 2012). In this study, the use of astaxanthin did not alter the sum of n-6 and n-3 nor the ratio n- $6 / n-3$, but all the concentrations of the bacterial biomass used as the pigmenting additive were able to enhance the sum of n-3 (Table 5). Moreover, the product at $350 \mathrm{mg} / \mathrm{kg}$ was also able to decrease the $\mathrm{n}-6$ PUFA in the fillets. Thus, the ratio $n-6 / n-3$ in the fillets was improved with all the concentrations of the biomass in the diets. So, the use of the product in tilapia fish feeding may bring an improvement for the meat quality.

Strobel et al. (2012) reported the contents of PUFA n-6 and n-3 of various fish species. Among them, the calculated ratio n-6/n-3 for tilapia (2.41) was close to the ratios found in this study for the control and astaxanthin-treated groups, but higher than the ratios found for the biomass-treated groups, especially with $350 \mathrm{mg} / \mathrm{kg}$.

So, it was concluded that the use of pigmenting ingredients in Nile tilapia feed did not alter the animals' performance and increased the redness and the carotenoids contents of the fillets. $R$. gelatinosus biomass also was able to increase the protein content and improve the fatty acids profile of the fillets.

Acknowledgments The authors would like to thank FAPESP for the financial support (2011/50274-4) and CAPES for the scholarship.

\section{References}

Albuquerque WF, Zapata JFF, Almeida RS (2004) Estado de frescor, textura e composição muscular da tilápia-do-Nilo (Oreochromis niloticus) abatida com dióxido de carbono e armazenada em gelo. Rev Ciên Agron 35:264-271

Baker RTM, Pfeiffer AM, Schöner FJ, Smith-Lemmon L (2002) Pigmenting efficacy of astaxanthin and canthaxanthin in fresh-water reared Atlantic salmon, Salmo salar. Anim Feed Sci Tech 99:97-106

Bhosale P, Bernstein PS (2005) Microbial xanthophylls. Appl Microbiol Biotechnol 68:445-455

Brambilla F, Forchino A, Antonini M, Rimoldi S, Terova G, Saroglia M (2009) Effect of dietary astaxanthin sources supplementation on muscle pigmentation and lipid peroxidation in rainbow trout (Oncorhynchus mykiss). Ital J Anim Sci 8:845-847

Breithaupt DE (2007) Modern application of xanthophylls in animal feeding: a review. Trends Food Sci Technol 18:501-506

Britton G, Liaaen-Jensen S, Pfander H (2009) Carotenoids: nutrition and health. Birkhäuser Verlag, Basel

Burger J (2008) Fishing, fish consumption and awareness about warnings in a university community in central New Jersey in 2007, and comparisons with 2004. Environ Res 108:107-116

Chaijan M (2011) Physicochemical changes of tilapia (Oreochromis niloticus) muscle during salting. Food Chem 129:1201-1210

Chociai MB, Machado IMP, Fontana JD, Chociai JG, Busato SB, Bonfim TMB (2002) Cultivo da levedura Phaffia rhodozyma (Xanthophyllomyces dendrorhous) em processo descontínuo alimentado para produção de astaxantina. Braz J Pharm Sci 38:457-462

Choubert G, Blanc JM, Vallée F (1997) Colour measurement, using the CIELCH colour space, of muscle of rainbow trout, Oncorhynchus mykiss (Walbaum), fed astaxanthin: effects of family, ploidy, sex, and location of reading. Aquac Res 28:15-22 
Christie WW (1975) A simple procedure for rapid transmethylation of glycerolipids and cholesteryl esters. J Lipid Res 23:1072

Czeczuga B, Semeniuk J, Czeczuga-Semeniuk E, Semeniuk A, Klyszejko B (2013) Amount and qualities of carotenoids in fillets of fish species fed natural feed in some fisheries of West African Coast. Afr $\mathbf{J}$ Biotechnol 12:1443-1448

De la Mora GI, Arredondo-Figueroa JL, Ponce-Palafox JT, Barriga-Soca I, Vernon-Carter JE (2006) Comparison of red chilli (Capsicum annuum) oleoresin and astaxanthin on rainbow trout (Oncorhyncus mykiss) fillet pigmentation. Aquaculture 258:487-495

Diler I, Dilek K (2002) Significance of pigmentation and use in aquaculture. Turk J Fish Aquat Sci 2:97-99

Duan ZH, Zhang M, Tang J (2004) Thin layer hot-air drying of bighead carp. Fish Sci 23:29-32

Emire SA, Gebremariam MM (2009) Influence of frozen period on the proximate composition and microbiological quality of Nile tilapia fish (Oreochromis niloticus). J Food Process Pres 34:743-757

Folch J, Lees M, Sloane-Stanley GH (1957) A simple method for the isolation and purification of total lipids from animal tissues. J Biol Chem 226:497-509

Food and Agriculture Organization of the United Nations (FAO) (2014) The state of world fisheries and aquaculture 2012. Food and Agriculture Organization of the United Nations, Rome

Furuya WM, Pezzato LE, Barros MM, Boscolo WR, Cyrino JEP, Furuya VRB, Feiden A (2010) Tabelas brasileiras para a nutrição de tilápias. http://www.lisina.com.br/noticias_detalhes.aspx?id=412 of subordinate document. Cited 31 July 2011

Hara A, Radin NS (1978) Lipid extraction of tissues with low-toxicity solvent. Anal Biochem 90:420-426

Horwitz W, Latimer GH Jr (2006) Official methods of analysis of AOAC International, 18th edn. AOAC International, Gaithersburg

$\mathrm{Hu}$ CJ, Chen SM, Pan CH, Huang CH (2006) Effects of dietary vitamin A or $\beta$-carotene concentrations on growth of juvenile hybrid tilapia, Oreochromis niloticus $\times$ O. aureus. Aquaculture 253:602-607

Justi KC, Hayashi C, Visentainer JV, Souza NE, Matsushita M (2003) The influence of feed supply time on the fatty acid profile of Nile tilapia (Oreochromis niloticus) fed on a diet enriched with n-3 fatty acids. Food Chem 80:489-493

Kubitza F (2000) Tilápia: tecnologia e planejamento na produção comercial. Fernando Kubitza, Jundiaí

Lovshin LL (2000) Criteria for selecting Nile tilapia and red tilapia for culture. In: Fitzsimmons K, Carvalho Filho J (eds) Tilapia aquaculture in the 21st century, Rio de Janeiro

Meyers SP, Chen HM (1982) Astaxanthin and its role in fish culture. In: Stickney RR, Meyers SP (eds) Proceeding of the warmwater fish culture, Louisiana

Moura MAM, Galvão JA, Henrique CM, Savay da Silva LK, Oetterer M (2009) Caracterização físicoquímica e de frescor de filés de tilápia do Nilo (Oreochromis niloticus) oriundas da pesca extrativista no médio rio Tietê/SP, Brasil. Bol Inst Pesca 35:487-495

Oliveira RQ, Goés-Neto A, Uetanabaro APT, Rosa CA, Assis SA (2009) Potencial biotecnológico de leveduras carotenogênicas: uma breve revisão. Sitientibus 9:48-51

Pacheco-Aguilar R, Lugo-Sanchez ME, Robles-Burgueno MR (2000) Postmortem biochemical characteristic of Monterey sardine muscle stored at $0^{\circ} \mathrm{C}$. J Food Sci 65:40-47

Park K, Gross M, Lee DH, Holvoet P, Himes JH, Shikany JM, Jacobs DR Jr (2009) Oxidative stress and insulin resistance. Diabetes Care 32:1302-1307

Ponsano EHG, Lacava PM, Pinto MF (2003) Chemical composition of Rhodocyclus gelatinosus biomass produced in poultry slaughterhouse wastewater. Braz Arch Biol Techn 46:143-147

Ponsano EHG, Lima LKF, Torres APC (2011) From a pollutant byproduct to a feed ingredient. In: Matovic D (ed) Biomass: detection, production and usage. Intech, Rijeka

Ponsano EHG, Avanço SV, Grassi TLM, Minello MCS, Santo EFE, Pinto MF, Garcia Neto M (2012) Microbial oxycarotenoids in broilers chicken rearing. In: Price M (ed) Proceedings international congress of meat science and technology, Montreal

Puwastien P, Judprasong K, Kettwan E, Vasanachitt K, Nakngamanong Y, Bhattacharjee L (1999) Proximate composition of raw and cooked Thai freshwater and marine fish. J Food Compos Anal 12:9-16

Rocha DN, Simões LN, Paiva G, Gomes LC (2012) Sensory, morphometric and proximate analyses of Nile tilapia reared in ponds and net-cages. R Bras Zootec 41:1795-1799

Santo EFE (2014) Rubrivivax gelatinosus na alimentação de tilápias para incrementar a qualidade dos filés. Thesis, Universidade Estadual Paulista

Sefc KM, Brown AC, Clotfelter ED (2014) Carotenoid-based coloration in cichlid fishes. Comp Biochem Phys A 173:42-51

Silva MC (2004) Alterações na biossíntese de carotenoides em leveduras induzidas por agentes químicos. Dissertation, Universidade Estadual de Campinas

Simopoulos AP (1999) Essential fatty acids in health and chronic disease. Am J Clin Nutr 70:560-569 
Simopoulos AP (2002) The importance of ratio omega-6/omega-3 essential fatty acids. Biomed Pharmacother 56:365-379

Siriwardhana N, Kalupahana NS, Moustaid-Moussa N (2012) Health benefits of n-3 polyunsaturated fatty acids: eicosapentaenoic acid and docosahexaenoic acid. Adv Food Nut Res 65:211-222

Stahl W, Sies H (2003) Antioxidant activity of carotenoids. Mol Asp Med 24:345-351

Strobel C, Jahreis G, Kuhnt K (2012) Survey of n-3 and n-6 polyunsaturated fatty acids in fish and fish products. Lipids Health Dis 11:1-10

Takahashi NS, Tsukamoto RY, Tabata YA, Rigolino MG (2008) Truta salmonada: processo produtivo em constante aprimoramento no Brasil. Panorama da Aquicultura 18:28-33

Takeuchi T, Lu J, Yoshizaki G, Satoh S (2002) Effect on the growth and body composition of juvenile tilapia Oreochromis niloticus fed raw Spirulina. Fish Sci 68:34-40

Watanabe WO, Losordo TM, Fitzsimmons K, Hanley F (2002) Tilapia production systems in the Americas: technological advances, trends, and challenges. Rev Fish Sci 10:465-498

Yanar Y, Çelic M, Akamca E (2006) Effects of brine concentration on shelf-life of hot-smoked tilapia (Oreochromis niloticus) stored at $4^{\circ} \mathrm{C}$. Food Chem 97:244-247

Yesilayer N, Erdem M (2011) Effects of oleoresin paprika (capsicum annum) and synthetic carotenoids (canthaxantin and astaxanthin) on pigmentation levels and growth in Rainbow trout Oncorhynchus mykiss W. J Anim Vet Adv 10:1875-1882 